\title{
Phytometal Availability, Evaluation of Antioxidant Activity and Total Phenolic Compounds of Genipa americana L. (Rubiaceae) Fruits
}

\author{
Oneil Valerio Avila ${ }^{1}$, Ismael Montero Fernández ${ }^{2}$, Habdel Nasser Rocha da $\operatorname{Costa}^{1}$, Ricardo Carvalho dos Santos ${ }^{3}$, \\ Pedro Rômulo Estevam Ribeiro, ${ }^{4}$ Valdinar Ferreira $\mathrm{Melo}^{2}$, Ana Cristina Gonçalves Reis de Melo ${ }^{4}$, \\ Ednalva Dantas Rodrigues da Silva Duarte ${ }^{2,5}$ \& Antonio Alves de Melho Filho ${ }^{1,2,5}$ \\ ${ }^{1}$ Post-Graduate Program in Chemistry, Center for Research and Graduate Studies in Science and Technology, \\ Federal University of Roraima, Paricarana Campus, Boa Vista, RR, Brazil \\ ${ }^{2}$ Postgraduate Program in Biodiversity and Biotecnology, Campus Cauamé, Boa Vista, RR, Brazil \\ 3 National Postdoctoral Program of CAPES, associated to the Postgraduate Program in Agronomy of \\ Universidade Federal de Roraima, Campus Cauamé, Boa Vista, RR, Brazil, and to the Brazilian Agricultural \\ Research Corporation, Embrapa, Boa Vista, RR, Brazil \\ ${ }^{4}$ Post-Graduate in Natural Resources Program, Federal University of Roraima, Paricarana Campus, Boa Vista, \\ RR, Brazil \\ ${ }^{5}$ Department of Chemistry, Federal University of Roraima, Paricarana Campus, Boa Vista, RR, Brazil \\ Correspondence: Oneil Valerio Avila, Post-Graduate Program in Chemistry, Center for Research and Graduate \\ Studies in Science and Technology, Federal University of Roraima, Paricarana Campus, CEP 69304-000, Boa \\ Vista, RR, Brazil. Tel: 55-95-991-709-579. E-mail: dragonquestfly88@gmail.com
}

Received: February 8, $2018 \quad$ Accepted: March 12, $2018 \quad$ Online Published: April 15, 2018

doi:10.5539/jas.v10n5p150 URL: https://doi.org/10.5539/jas.v10n5p150

\begin{abstract}
The present work studied the fruits of genipap (Genipa americana L.) occurring in the city of Boa Vista, Roraima, State, Brazil. The content of the following minerals being evaluated: $\mathrm{B}, \mathrm{Ca}, \mathrm{Cu}, \mathrm{Fe}, \mathrm{Mg}, \mathrm{Mn}, \mathrm{Na}, \mathrm{P}, \mathrm{Zn}$ and their antioxidant activity on pulp, peel, seeds and oil extracted from the seeds. The levels of the minerals present in the different parts of the fruit were analyzed by flame atomic absorption spectroscopy (FAAS), flame atomic emission spectrometry (FAES) and UV-visible spectroscopy (UV/VIS). The mineral with the highest content was the potassium found in the peel $\left(1,248.48 \pm 4.59 \mathrm{mg} \cdot 100 \mathrm{~g}^{-1}\right)$. The studies showed that the phenolic compounds are closely related to the antioxidant activity, in this study the peel presented the highest phenolic compounds content $712.21 \pm 11.04 \mathrm{mg} \mathrm{GAE} \cdot 100 \mathrm{~g}^{-1}$ and the pulp showed the highest capacity of Capture of the DPPH free radical of $661.34 \pm 17.12 \mathrm{EC}_{50} \mathrm{mg} \cdot \mathrm{mL}^{-1}$, thus the genipap is a fruit with a potential food of the Roraima region.
\end{abstract}

Keywords: Amazon, DPPH, FAAS, genipap, minerals, UV/VIS

\section{Introduction}

According to De-Souza, Rossi, Varella, Silveira, and Souza (2016), the Amazon is considered and known as one of the regions suitable for fruit production, due to its great diversity of native plants that grow and develop. These plants have multiple uses for humans, thus having a multidisciplinary connotation, because they are used in different areas of study (Maciel, Pinto, \& Veiga Jr., 2002). Among some of the uses, we have: it has been used as a food, medicine, conservation, folklore and more, thus gaining an important role in daily life (Martins, Rosário, Barros, \& Jardim, 2005).

Genipap tree it is widely distributed in tropical Central America and South America. The species is present throughout Brazil, naturally or cultivated, from the Amazon to São Paulo and Mato Grosso, in various forest formations (Mors, Rizzini, Pereira, \& Defillipps, 2000).

Genipa americana is a specie of economic importance, since its fruits are consumed naturally or used for the production of sweets, jellies and liquors (Lorenzi, 1992; Rabbani, Silva-Mann, \& Ferreira, 2012). In addition to its use as food according to Soares, Sousa, Garrido, and Lima (2012), fruits, leaves, roots and trunk are used as remedy in folk medicine. Among the known biological activities we have: antiulcerogenic, anticarcinogenic, antidireretic, antiasmatic, antianemic, anti-inflammatory, antifungal and antioxidant (Silva et al., 2015). G. 
americana fruits are considered as health promoters because they contain minerals such as potassium, calcium, iron, zinc, phosphorus, copper, manganese and boron (Luzia, 2012).

According to Food and Agriculture Organization of the United Nations, Brazil is one of the three largest fruit producers in the world and the first in Latin America and the Caribbean (FAO, 2014). Fruits are important sources of essential nutrients in the human diet (vitamins, minerals, fatty acids, proteins, carbohydrates, etc.); for the population to consume nutrients in a balanced way is important for many daily activities and prevent diseases; however, the necessary levels of nutrients can be achieved by consuming the whole fruit (peel, pulp, seeds) (Gondim, Moura, Dantas, Medeiros, \& Santos, 2005).

Panato et al. (2007) argue that fruit consumption has been strongly associated with reducing risks for many cancers, due to its antioxidant actions, it is estimated that $60 \%$ to $70 \%$ of cancers are directly related to our eating and other habits factors of our lifestyle.

Therefore, the objective of this work is to perform a mineralogical and antioxidant study of the different parts of the genipap fruit (peel, pulp, seeds), as well as to determine the same analysis in the oil extracted from its seeds.

\section{Method}

\subsection{Plant Material and Extraction of Vegetable Oil}

The genipap fruits were harvested mature from the same individual, from different parts of the tree in the municipality of Boa Vista-RR (Brazil) in April 2016 at the following coordinate's 2 ${ }^{\circ} 50^{\prime} 01.5^{\prime \prime} \mathrm{N} 60^{\circ} 42^{\prime} 21.6^{\prime \prime} \mathrm{W}$. They were exsiccated, deposited and identified in the herbarium of the Federal University of Roraima (UFRR), with a voucher number 8797. The fruits were taken to the Environmental Chemistry Laboratory (LQA), Paricarana campus, in the Nucleus of Research and Postgraduate in Science and Technology (NPPGCT) of the UFRR, which were washed and cleaned with distilled water, then dried and then separated into shell, pulp and seeds. These were weighed and stored in a freezer at $-20{ }^{\circ} \mathrm{C}$ for lyophilization. The lyophilization of the seeds was carried out in a LIOTOP lyophilizer, model L101, for 48 hours until complete drying of the material in the Physics and Land Management Laboratory at the Agricultural Sciences Center (LFMSCSA), Cauamé campus of the UFRR. Subsequently, the material was ground in MARCONI® knife mill, sieved until homogenization of the particles between 20-40 Mesh, and then stored under cover of light.

The vegetable oil was obtained using a Soxlhet extractor with cartridges lined with cotton containing $47 \mathrm{~g}$ (seeds) crushed and plus $500 \mathrm{~mL}$ of hexane solvent for each extraction (Jorge \& Luzia, 2012). The extraction was carried out in a period of 3 hours under reflux of the solvent, and then the obtained mixture passed through a separation process using a vacuum rotoevaporator, separating the vegetable oil from the solvent accordance with the norm of the Adolfo Lutz Institute (IAL, 2008).

\subsection{Mineralogical Analysis}

The extraction of the minerals in different parts of the fruit and the oil extracted from the seeds was done according to the methodology described by Da Silva (2009). Calcium (Ca), magnesium (Mg), iron (Fe), copper $(\mathrm{Cu})$, zinc $(\mathrm{Zn})$ and manganese $(\mathrm{Mg})$ were determined by flame atomic absorption spectrophotometry on a coupled SHIMADZU AA-7000 with simple auto ASC-7000. In the case of sodium (Na) was determined in the same equipment only that operating in the mode of atomic emission.

For the determination of phosphorus (P) and boron (B), the ultraviolet molecular absorption spectrophotometry technique was used using a SHIMADZU model UV-1800, according to the Da Silva (2009) methodology.

\subsection{Determination of Total Phenolic Compounds and Evaluation of Antioxidant Activity}

\subsubsection{Follin-Ciocalteau Method for the Determination of Total Phenolic Compounds}

The determination of Total Phenolic Compounds (CFT) was done according to the methodology described by Wolfe, $\mathrm{Wu}$, and Liu (2003), where methanolic extracts prepared from the extraction of $4 \mathrm{~g}$ of each lyophilized sample were used $35 \mathrm{~mL}$ of $80 \%(\mathrm{v} / \mathrm{v})$ ethanol acidified with $0.5 \%(\mathrm{v} / \mathrm{v})$ active principle grade hydrochloric acid $(\mathrm{HCl})$ in each extract was added and the tubes were placed in a water bath at $90{ }^{\circ} \mathrm{C}$ for 30 minutes. The supernatant was withdrawn and stored in another tube and $35 \mathrm{~mL}$ of the same solvent was added and treated under the same conditions as above. The fractions were then collected and centrifuged at $6,000 \mathrm{rpm}$ for 30 minutes and stored in a refrigerator at $2{ }^{\circ} \mathrm{C}$ in the absence of light to avoid degradation until the analysis.

The content of total phenolic compounds was determined by the Folin-Ciocalteau spectrophotometric method according to methodology proposed by Singlenton, Orthofer, and Raventos (1999), and gallic acid was used as the reference standard. This method involves the reduction of the reagent by the phenolic compounds of the samples with formation of a blue complex. An aliquot of $0.1 \mathrm{~mL}$ the extracts was transferred to a $10 \mathrm{~mL}$ test tube 
and $3 \mathrm{~mL}$ of distilled water was added followed by $0.25 \mathrm{~mL}$ of $7.5 \%(\mathrm{w} / \mathrm{v})$ sodium carbonate $\left(\mathrm{Na}_{2} \mathrm{CO}_{3}\right)$. A blank test was conducted under the same conditions, so that $0.1 \mathrm{~mL}$ of distilled water was used in place of the sample. The samples were protected with foil and taken to a bath with distilled water at $37^{\circ} \mathrm{C}$ for 30 minutes.

The absorbance reading was performed on a pre-calibrated spectrophotometer using $765 \mathrm{~nm}$ wavelengths, the quantification of total phenols in triplicate extracts was expressed in $\mathrm{mg} \mathrm{GA} \cdot 100 \mathrm{~g}^{-1}$ of sample.

\subsubsection{Evaluation of Antioxidant Activity by DPPH}

The DPPH method according to Brand-Williams, Cuvelier, and Berset (1995), is based on the capture of the DPPH (2,2-diphenyl-1-picryl-hydrazyl) radical by antioxidants, producing a decrease in absorbance at $515 \mathrm{~nm}$, a change from dark violet to light violet in the presence of antioxidant compounds.

The DDPH method was developed using visible ultraviolet molecular absorption spectrophotometry measured at $515 \mathrm{~nm}$ (Miranda \& Fraga, 2006) on the Shimadzu UV-1800 model. The technique consists in preparing a 300 $\mu \mathrm{L}$ incubation of the methanolic extract with $2.7 \mathrm{~mL}$ of $0.06 \mu \mathrm{M}$ DPPH solution, leaving for 60 minutes in incubation and obscurity to be read later at $515 \mathrm{~nm}$. The calibration curve was made by preparing diluted standards from the $60 \mu \mathrm{M}$ stock concentration in the range of 10 to $50 \mu \mathrm{M}$ and at the same time the blank was made with methanol.

To determine the percentage of antiradical activity (\%) was used Equation 1,

$$
\% \text { Antiradical Activity }=(A D P P H-A s / A D P P H) \times 100
$$

Where $\mathrm{ADPPH}=$ Control Absorbance; As $=$ Sample Absorbance .

\subsubsection{Evaluation of Antioxidant Activity by Reduction of Iron}

The method of iron reduction with modifications, based on the ability of the antioxidant compounds to reduce $\mathrm{Fe}^{3+}$ to $\mathrm{Fe}^{2+}$, by reading the color variation produced in the chromogenic ligand selectively bound to iron.

$$
\begin{gathered}
2_{\mathrm{n}}\left[\mathrm{Fe}(\mathrm{CN})_{6}\right]^{3-}+\mathrm{Ar}(\mathrm{OH})_{\mathrm{n}} \rightarrow 2_{\mathrm{n}}\left[\mathrm{Fe}(\mathrm{CN})_{6}\right]^{4-}+\mathrm{Ar}(=\mathrm{O})_{\mathrm{n}}+2_{\mathrm{n}} \mathrm{H}^{+} \\
{\left[\mathrm{Fe}(\mathrm{CN})_{6}\right]^{4-}+\mathrm{Fe}^{3+} \rightarrow \mathrm{Fe}\left[\mathrm{Fe}(\mathrm{CN})_{6}\right]^{-}}
\end{gathered}
$$

The compound $\left[\mathrm{Fe}(\mathrm{CN})^{6}\right]^{3-}$ in the presence of antioxidant compounds $\mathrm{Ar}(\mathrm{OH})^{\mathrm{n}}$ produce the reduction of the ferrocyanine $\left[\mathrm{Fe}(\mathrm{CN})^{6}\right]^{4-}$ and oxidized antioxidant $\operatorname{Ar}(=\mathrm{O})^{\mathrm{n}}$ when the ferrocyanin stabilizes by $\mathrm{Fe}^{3+},\left(\mathrm{FeCl}_{3}\right)$, will act as a chromogenic reagent, being read in the spectrophotometer at $690 \mathrm{~nm}$ (Berker, Güçlü, Tor, Demirata, \& Apak, 2010).

The methodology used was described by Barros, Heleno, Carvalho, and Ferreira (2010), using different concentrations of the ethanol extracts. $0.5 \mathrm{~mL}$ aliquots of each concentration were mixed with $0.5 \mathrm{~mL}$ sodium phosphate buffer $\left(200 \mathrm{mmol} \mathrm{L}^{-1}, \mathrm{pH} 6.6\right)$ and $0.5 \mathrm{~mL}$ potassium ferrocyanide $(1 \% \mathrm{w} / \mathrm{v}$, in water). The mixture was incubated for 20 minutes at $50{ }^{\circ} \mathrm{C}$ using $0.5 \mathrm{~mL}$ of trichloroacetic acid $(10 \% \mathrm{w} / \mathrm{v})$ to stop the reaction.

Subsequently, an aliquot of $1.5 \mathrm{~mL}$ of the blend was transferred to a tube test with $1.5 \mathrm{~mL}$ of deionized water and $0.16 \mathrm{~mL}$ of iron chloride $(0.1 \% \mathrm{w} / \mathrm{v})$, making the absorbance readings at $690 \mathrm{~nm}$ in the previously calibrated UV-1800 ultraviolet-visible molecular absorption spectrophotometer.

\section{Results and Discussion}

\subsection{Mineralogic Analisys}

According to Fernandes (2006), potassium (K) is the most abundant cation in the plant having an important function in the energy state of the plant activating more than 60 enzymatic systems. According to FAO (1989), potassium is the major cation of intracellular fluids, performing functions such as regulating intracellular osmotic pressure and acid-base balance. The World Health Organization suggests that adults consume at least 3,510 $\mathrm{mg}$ /day (WHO, 2003).

In the different parts of the studied fruit, the peel presented the highest concentration of potassium $(1,248.48$ $\mathrm{mg} / 100 \mathrm{~g}$ ). According to similar studies with banana peels (Musa sp.), Pineapple (Ananas comosus) and mandarin (Citrus reticulata) present concentrations of $300.92 \mathrm{mg} \cdot 100 \mathrm{~g}^{-1}, 285.87 \mathrm{mg} \cdot 100 \mathrm{~g}^{-1}$ and $598.36 \mathrm{mg} \cdot 100$ $\mathrm{g}^{-1}$, respectively (Gondim et al., 2005).

Among the minerals studied, phosphorus (P) plays a role in the metabolic functions of the plant, such as energy transfer, photosynthesis, and others (Fernandes, 2006). According to FAO (1989) within the main biological functions within animal life we have that phosphorus is an essential component in bone, cartilage, phospholipids and plays a central role in cellular and energy metabolism. Studies indicate that the recommended daily intake of $\mathrm{P}$ is $800 \mathrm{mg}$ /day (Gabarra, 2006). 
Within the analyzes, the pulp had the highest concentration of phosphorus $\left(43.05 \mathrm{mg} \cdot 100 \mathrm{~g}^{-1}\right)$. In works done by Franco (1982), with genipap pulp found a concentration of $29.00 \mathrm{mg} \cdot 100 \mathrm{~g}^{-1}$. The difference value may be due to the techniques of analysis used were distinct, FAAS and titration respectively. In studies carried out by Junior (2003), with fresh fruit of wolf-fruit (Solanum lycocarpum), which presented concentrations close to 35.5 $\mathrm{mg} \cdot 100 \mathrm{~g}^{-1}$.

Another mineral studied was calcium $(\mathrm{Ca})$, whose main biological function in the plant is related to its coordination capacity, to form reversible intermolecular bonds (Monge, Val, Sanz, Blanco, \& Montañés, 1994) and this element participates in the elongation, cell division and structure of the the cellular wall (Cooman, Torres, \& Fischer, 2005). Calcium in the human body represents $1.5-2.0 \%$ of body weight (bone tissue, teeth and blood) being the fifth most abundant element in the human body (Marques, 2008), and for Nogueira (2008) its deficiency can lead to diseases such as osteoporosis in advanced ages. Calcium levels for pregnant women recommended by FAO (2002) are 1,000 mg/day and for adults it is $500 \mathrm{mg} /$ day.

The fruit analysis in this study shows that the highest concentration of calcium was found in the pulp (33.25 $\mathrm{mg} \cdot 100 \mathrm{~g}^{-1}$ ). Compared with studies by Figueiredo, Maia, Holanda, and Monteiro (1986), in mature genipap pulp presented a concentration of $45.82 \mathrm{mg} \cdot 100 \mathrm{~g}^{-1}$ and studies by Franco (1982), in genipap pulp found a concentration of $33.00 \mathrm{mg} \cdot 100 \mathrm{~g}^{-1}$.

According to Ross (2004), the magnesium (Mg) plays a role in the plant as the central atom of the chlorophyll molecule in the process of photosynthesis, protein syntheses and energy transfer. However, magnesium in the human body plays the role as a cofactor in more than three hundred intracellular enzymes, being the fourth most abundant cation in the human body (Tresguerres et al., 2005). Studies by Gabarra (2006) indicate that the recommended daily intake of $\mathrm{Mg}$ is $300 \mathrm{mg} \cdot \mathrm{day}^{-1}$.

The analyzes carried out on the different parts of the genipap fruit showed the highest concentration of $\mathrm{Mg}$ found in the pulp and was of $7.05 \mathrm{mg} \cdot 100 \mathrm{~g}^{-1}$, works done in the avocado pulp (Persea americana) presented a concentration of $41 \mathrm{mg} \cdot 100 \mathrm{~g}^{-1}$ (Tovar, 2003). Other studies carried out on edible parts of mandarin (Citrus reticulata) and melon (Cucumis melo) are concentrated at $8 \mathrm{mg} \cdot 100 \mathrm{~g}^{-1}$ and $6 \mathrm{mg} \cdot 100 \mathrm{~g}^{-1}$, respectively (Gondim et al., 2005).

According to Fernandes (2006) Copper $(\mathrm{Cu})$ is found in the plant in small concentrations, oxidation of ascorbic acid and present as a constituent in certain enzymes, are some of the functions of $\mathrm{Cu}$ in the plant. Copper in the human body participates in the formation of hemoglobin and is fundamental for the development and maintenance of bones, tendons, connective tissue and vascular system (Maury et al., 2010). Studies indicate that copper intake for men and adult women are $900 \mathrm{mg} \cdot \mathrm{day}^{-1}$ (Murray, 2014). The analyzes performed on the fruit showed that there is a higher concentration of $\mathrm{Cu}$ in the seeds $\left(1.69 \mathrm{mg} \cdot 100 \mathrm{~g}^{-1}\right)$ and in comparison with studies made with genipap seeds found a $\mathrm{Cu}$ concentration of $0.65 \mathrm{mg} \cdot 100 \mathrm{~g}^{-1}$ (Luzia, 2012).

Iron in the plant plays a key role in the activation of enzymes, it also participates in oxidation reduction reactions (Fernandes, 2006), in the human body iron is necessary to produce hemoglobin, it is also a component of many enzymes and its deficiency is the main cause of anemia worldwide (García, 2002). The recommended iron levels per day according to FAO (2002) are $10 \mathrm{mg} \cdot \mathrm{day}^{-1}$ for adult men and for adult women it is $18 \mathrm{mg} \cdot \mathrm{day}^{-1}$.

The analyzes made in the different parts of the fruit, the highest concentration of iron was found in the peel (6.90 $\mathrm{mg} \cdot 100 \mathrm{~g}^{-1}$ ) and the pulp that is the edible part was $3.67 \mathrm{mg} \cdot 100 \mathrm{~g}^{-1}$, already in the seeds presented a concentration of $3.35 \mathrm{mg} \cdot 100 \mathrm{~g}^{-1}$. Compared with studies by Franco (1982), a concentration in the genipap pulp was $3.40 \mathrm{mg} \cdot 100 \mathrm{~g}^{-1}$ and in studies by Luzia (2012), with genipap seeds was found a Fe concentration of 3.31 $\mathrm{mg} \cdot 100 \mathrm{~g}^{-1}$. Studies by Gondim et al. (2005) in avocado bark (Persea americana) and mandarin (Citrus reticulata) present a concentration of $2.18 \mathrm{mg} \cdot 100 \mathrm{~g}^{-1}$ and $4.77 \mathrm{mg} \cdot 100 \mathrm{~g}^{-1}$, respectively.

Manganese (Mn) plays a role in the synthesis of chlorophyll, but its main function is to participate in the activation of enzymes (Fernandes, 2006). According to García (2002), in the human body manganese acts at the enzymatic level, in the enzyme superoxide dismutase (SOD) that plays an important role in antioxidant processes. Studies by the Agency for Toxic Substances and Disease Registry (ATSDR) indicate that the daily intake of manganese ranges from 1-10 $\mathrm{mg} \cdot \mathrm{day}^{-1}$ (ATSDR, 2012).

In different parts of the studied fruit, the seeds had the highest concentration of manganese $\left(3.57 \mathrm{mg} \cdot 100 \mathrm{~g} \mathrm{~g}^{-1}\right)$ and the lowest concentration of the pulp $\left(1.01 \mathrm{mg} \cdot 100 \mathrm{~g}^{-1}\right)$. Compared with studies with genipap seed, was found a concentration of Mn of $0.60 \mathrm{mg} \cdot 100 \mathrm{~g}^{-1}$ (Luzia, 2012). Studies by Menezes, Torres, and Srur (2008) with açaí fruit pulp (Euterpe oleracea) found a Mn concentration of $10.71 \mathrm{mg} \cdot 100 \mathrm{~g}^{-1}$. 
The function of zinc ( $\mathrm{Zn}$ ) in the plant according to Fernandes (2006) is to act as enzymatic cofactor, regulation and stabilization of the protein structure. Zinc helps the body to have a normal development and growth; in addition, it participates to maintain the effectiveness of the immune system (Maury et al., 2010). Studies by Murray (2014) indicate that zinc intake in adult men and women are $11 \mathrm{mg} \cdot \mathrm{day}^{-1}$ and $8 \mathrm{mg} \cdot \mathrm{day}^{-1}$ respectively.

The analysis of the different parts of the fruit, the highest concentration of zinc was found in the pulp (3.94 $\mathrm{mg} \cdot 100 \mathrm{~g}^{-1}$ ), in comparison with studies done on banana pulp (Musa sp.), Which had a concentration of 0.6 $\mathrm{mg} \cdot 100 \mathrm{~g}^{-1}$ (Gondim et al., 2005).

Another of the minerals studied was Boron (B), which for Kirkby and Romheld (2007) its function in the plant is to contribute as a constituent of the cell wall and membranes, is also involved in reproductive growth. In the human body, it plays a role in the maintenance of healthy bones, especially in the case of deficiencies of vitamin D and Mn (Schaafsma, Vries, \& Saris, 2001). Studies indicate that the daily needs of B are $0.5-1 \mathrm{mg} \cdot \mathrm{day}^{-1}$ (Crespo, 2001).

In the different parts of the studied fruit, the peel presented the highest boron concentration of $1.46 \mathrm{mg} .100 \mathrm{~g}^{-1}$ and pulp with a concentration of $1.03 \mathrm{mg} \cdot 100 \mathrm{~g}^{-1}$, while in the seeds $0.96 \mathrm{mg} \cdot 100 \mathrm{~g}^{-1}$. Studies on fruits of Jatropha curcas, found a concentration of $23.50 \mathrm{mg} \cdot \mathrm{kg}^{-1}\left(2.35 \mathrm{mg} \cdot 100 \mathrm{~g}^{-1}\right)$ (Laviola \& Dias, 2008). Other studies by Luzia (2012) with genipap seeds found a B concentration of $0.89 \mathrm{mg} \cdot 100 \mathrm{~g}^{-1}$.

Sodium $(\mathrm{Na})$ in the plant has as main function to replace potassium in metabolic and osmotic functions, but in some plant species sodium is considered as an essential element, however for most of these species it is toxic in high concentrations (Fernandes, 2006). For Tortara and Derrickson (2017) in the human body sodium is necessary in conducting nerve and muscle action potentials. About adult sodium intake, WHO (2013) recommends that it be $2.000 \mathrm{mg}^{- \text {day }^{-1}}$ (equivalent to $5.000 \mathrm{mg}$ of salt $\cdot \mathrm{day}^{-1}$ ).

Analyzes made on the different parts of the fruit, the highest concentration of sodium was found in the seeds $\left(0.71 \mathrm{mg} \cdot 100 \mathrm{~g}^{-1}\right)$ and in the peel with a similar concentration of $0.69 \mathrm{mg} \cdot 100 \mathrm{~g}^{-1}$. Studies on melon peel presented a concentration of $8.54 \mathrm{mg} \cdot 100 \mathrm{~g}^{-1}$ (Gondim et al., 2005), other studies with genipap seeds found a Na concentration of $244.15 \mathrm{mg} \cdot 100 \mathrm{~g}^{-1}$ (Luzia, 2012).

In these studies made to G. americana, considerable mineral content was observed, can you see in Table 1 being found in all parts of the fruit. Considering the pulp the most important part, since it is the edible part and the one consumed by the people, thus taking into account the studies carried out by the different authors and the results obtained in this work, the consumption of genipap can be a good option in the diet by its potential in minerals.

Table 1. Mineralogical analysis

\begin{tabular}{|c|c|c|c|c|c|c|c|c|c|}
\hline \multirow{2}{*}{ Genipa americana } & \multicolumn{9}{|c|}{ Minerals $\left(\mathrm{mg} \cdot 100 \mathrm{~g}^{-1}\right)$} \\
\hline & $\mathrm{Na}$ & $\mathrm{P}$ & $\mathrm{Mg}$ & $\mathrm{Cu}$ & $\mathrm{Ca}$ & $\mathrm{Mn}$ & $\mathrm{Fe}$ & B & $\mathrm{Zn}$ \\
\hline Pulp & $0.67 \pm 0.00$ & $43.05 \pm 0.08$ & $7.05 \pm 0.17$ & $0.23 \pm 0.00$ & $33.25 \pm 0.01$ & $1.01 \pm 0.01$ & $3.68 \pm 0.06$ & $1.04 \pm 0.08$ & $3.94 \pm 0.03$ \\
\hline Peel & $0.69 \pm 0.00$ & $40.62 \pm 0.02$ & $5.79 \pm 0.03$ & $0.64 \pm 0.04$ & $11.09 \pm 0.08$ & $1.91 \pm 0.00$ & $6.90 \pm 0.08$ & $1.46 \pm 0.05$ & $2.61 \pm 0.00$ \\
\hline Seed & $0.71 \pm 0.00$ & $26.76 \pm 0.18$ & $1.54 \pm 0.02$ & $1.69 \pm 0.01$ & $0.16 \pm 0.01$ & $3.58 \pm 0.04$ & $3.36 \pm 0.06$ & $0.97 \pm 0.05$ & $3.61 \pm 0.02$ \\
\hline Seed Oil & $0.36 \pm 0.01$ & $16.02 \pm 0.30$ & $0.44 \pm 0.01$ & $0.70 \pm 0.25$ & $0.01 \pm 0.02$ & $2.12 \pm 0.05$ & $0.11 \pm 0.02$ & $0.33 \pm 0.03$ & $1.62 \pm 0.01$ \\
\hline
\end{tabular}

\subsection{Antioxidant Activity and Total Phenols}

According to Rocha and collaborators, antioxidants (AO) are substances that in low concentrations compared to the oxidant substrate, have the ability to delay or inhibit oxidation reactions (Rocha, Pereira, Kaplan, \& Teixeira, 2007). Antioxidant activity in foods, such as fruits and vegetables, is attributed to its content of phenolic compounds acting as hijackers of free radicals in the body, helping to prevent chronic diseases and thus increasing their importance in the human diet (Canuto, 2010; Costa, 2015).

Methods for determining the antioxidant capacity of a substance are divided into those based on the capture of the peroxyl radical, the capture of the hydroxyl radical, capture of the organic radical and in the quantification of products formed during lipid peroxidation (Rufino et al., 2007). The part of the genipap fruit that presented the highest antioxidant capacity with both techniques was the pulp where $661.34 \mathrm{EC}_{50}\left(\mathrm{mg} \cdot \mathrm{mL}^{-1}\right)$ for DPPH and $107.12 \mu \mathrm{mol} \mathrm{Fe} \mathrm{SO}_{4} \cdot \mathrm{g}^{-1}$, can you see in Table 2. Studies with freeze-dried pulps and frozen genipap pulps in Salvador, Bahia presented a content of 74.51 and $442.80 \mathrm{EC}_{50}\left(\mathrm{mg} \cdot \mathrm{mL}^{-1}\right)$, respectively (Rezende, 2010). Other studies with genipap pulp presented a content of $606.7 \mathrm{EC}_{50}\left(\mathrm{mg} \cdot \mathrm{mL}^{-1}\right)$ (Porto et al., 2014). 
Phenols are chemical compounds widely distributed in fruits and vegetables; they are part of so-called secondary metabolites in plants, constituting a large group of substances with a wide variety of structures chemical and metabolic activities (Porras \& López, 2009). Phenolic compounds can be found naturally in foods, and their importance lies in their potential as antioxidants, an activity that is associated with the prevention of chronic diseases (Giada \& Mancini-Filho, 2006).

In the studies made to different parts of genipap and its oil, the highest total phenol content was found in the peel (712.21 mg GAE·100 g $\mathrm{g}^{-1}$ ) and pulp (394.71 mg GAE·100 g $\mathrm{g}^{-1}$ ) can you see in Table 2, studies by Omena and researchers with genipap fruits found the highest content of phenolic compounds in the peel $(187.7 \pm 11.3 \mathrm{mg}$ GAE $100 \mathrm{~g}^{-1}$ ) (Omena et al., 2012) and studies with lyophilized genipap pulps in the city of Salvador, Bahia presented a content of $686.71 \mathrm{mg} \mathrm{GAE} \cdot 100 \mathrm{~g}^{-1}$ (Rezende, 2010). Other studies with genipap fruits in the state of Piauí presented a content of $406.00 \mathrm{mg} \mathrm{GAE} \cdot 100 \mathrm{~g}^{-1}$ (Porto et al., 2014). Other works made with genipap fruits still in Salvador presented a content of $178.07 \mathrm{mg} \mathrm{GAE} / 100 \mathrm{~g}$ (Santana Neta, 2014) and oil studies of genipap seeds in Piauí, presented a range between 150 and $160 \mathrm{mg} \mathrm{GAE} \cdot 100 \mathrm{~g}^{-1}$ (Luzia, 2012).

The genipap pulp in this study had a higher total phenol content compared to other fruits consumed in Brazil, as

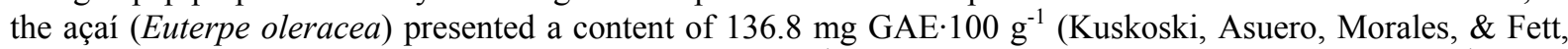
2006), bacuri (Platonia insignis) of $266.8 \mathrm{mg} \mathrm{GAE} \cdot 100 \mathrm{~g}^{-1}$, banana (Musa sp.) of $117.8 \mathrm{mg} \mathrm{GAE} \cdot 100 \mathrm{~g}^{-1}$, buriti (Mauritia flexuosa) of $108.1 \mathrm{mg}$ GAE $100 \mathrm{~g}^{-1}$ and murici (Byrsonima crassifolia) of $384.5 \mathrm{mg}$ GAE $100 \mathrm{~g}^{-1}$ (Barreto, Benassi, \& Mercadante, 2009).

It has been known and suggested that the content of phenolic compounds in different parts of a plant is correlated with its antioxidant activity (Velioglu, Mazza, \& Oomah, 1998). These natural antioxidants present in the plant as phenolic compounds (flavonoids, phenolic acids, alcohols, tocopherols, tocotrienols), ascorbic acid and carotenoids, reduce the rate of oxidation reactions by one or more mechanisms (Mattos, Moretti, Muniz, \& Silva, 2009).

Table 2. Antioxidant activity and total phenols

\begin{tabular}{|c|c|c|c|}
\hline \multirow{2}{*}{ Genipap } & \multicolumn{2}{|c|}{ Antioxidant Capacity } & \multirow{2}{*}{$\begin{array}{c}\text { Totals Phenols } \\
\text { mg Gallic Acid } \cdot 100 \mathrm{~g}^{-1} \text { sample }\end{array}$} \\
\hline & $\mathrm{DPPH} \mathrm{EC}_{50}\left(\mathrm{mg} \cdot \mathrm{mL}^{-1}\right)$ & Iron Reduction $\mathrm{mol} \mathrm{Fe}_{2} \mathrm{SO}_{4} \cdot \mathrm{g}^{-1}$ & \\
\hline Pulp & $661.34 \pm 17.12$ & $107.12 \pm 23.31$ & $394.71 \pm 17.12$ \\
\hline Peel & $803.32 \pm 12.04$ & $304.56 \pm 31.04$ & $712.21 \pm 11.04$ \\
\hline Seed & $2,357.94 \pm 64.12$ & $245.12 \pm 17.12$ & $218.14 \pm 21.17$ \\
\hline Seed Oil & $*$ & $74.12 \pm 1.15$ & $183.07 \pm 32.04$ \\
\hline
\end{tabular}

Note. * The DPPH technique is not used for oils and fats, it is necessary to use another solvent (Castelo-Branco \& Torres, 2011).

\section{Conclusion}

This work shows the nutritional importance of a fruit that is not yet widely considered in the market. The three parts of the same have an energetic importance, being of smaller contribution the pulp can be used for the consumption in natura, as well as for the preparation of jellies, ice creams and other type of snack.

The highest concentration of mineral found in G. americana fruits was potassium, which was evidenced using the flame photometry technique. The technique of atomic absorption showed that the fruits possess a considerable content of iron and zinc, these nutrients are essential elements for human health, being this fruit, an important alternative food. It was possible to observe the antioxidant activity in the different parts of the fruit using the UV-visible spectroscopy technique, with the pulp of the fruit presenting the highest activity 661.34 $\mathrm{mg} \cdot \mathrm{mL}^{-1}$. Generally, this antioxidant activity has been correlated with the presence of phenolic compounds.

\section{Acknowledgements}

We are grateful to CAPES for the scholarship received, Oleochemicals Research Group and laboratory of Physics and soil management UFRR for supporting the development this research.

\section{References}

ATSDR (Agency for Toxic Substances and Disease Registry). (2012). Toxicological profile for manganese. U.S. Department of Health and Human Services, USA. Retrieved from https://www.atsdr.cdc.gov/ToxProfiles/ tp151.pdf 
Barreto, G. P. M., Benassi, M. T., \& Mercadante, A. Z. (2009). Bioactive compounds from several tropical fruits and correlation by multivariate analysis to free radical scavenger activity. J. Braz. Chem. Soc., 20(10), 1856-1861. https://doi.org/10.1590/S0103-50532009001000013

Barros, L., Heleno, S. A., Carvalho, A. M., \& Ferreira, I. C. F. R. (2010). Lamiaceae often used in Portuguese folk medicine as a source of powerful antioxidants: Vitamins and phenolics. LWT Food Science and Technology, 43(3), 544-550. https://doi.org/10.1016/j.lwt.2009.09.024

Berker, K. I., Güçlü, K., Tor, I., Demirata, B., \& Apak, R. (2010). Total Antioxidant Capacity Assay Using Optimized Ferricyanide/Prussian Blue Method. Food Anal. Methods, 3(3), 154-168. https://doi.org/10.1007/ s12161-009-9117-9

Brand-Williams, W., Cuvelier, M. E., \& Berset, C. (1995). Use of a free radical method to evaluate antioxidant activity. Food Science and Technology, 28(1), 25-30. https://doi.org/10.1016/S0023-6438(95)80008-5

Canuto, G. A. B., Xavier, A. A. O., Neves, L. C., \& Benassi, M. T. (2010). Physical and chemical characterization of fruit pulps from Amazonia and their correlation to free radical scavenger activity. Revista Brasileira de Fruticultura, 32(4), 1196-1205. https://doi.org/10.1590/S0100-29452010005000122

Cooman, A., Torres, C., \& Fisches, G. (2005). Determinación de las causas del rajado del fruto de uchuva (Physalis peruviana L.) bajo cubierta. II. Efecto de la oferta de calcio, boro y cobre. Agronomía Colombiana, 23(1), 74-82.

Costa, M. C. (2015). Compostos Bioativos e Atividade Sequestrante de Radicais Livres de quatro cultivares do Coffea arábica L. em diferentes estádios de maturação dos frutos (Master dissertation, Paulista State University, Brazil).

Crespo, E. (2001). El boro, elemento nutricíonal essencial en la funcionalidad ósea. Revista Española de Cirugía Osteoarticular, 88(36), 88-95.

Da Silva, F. C. (2009). Manual de análises químicas de solos, plantas e fertilizantes. Brasilia: Embrapa.

De-Souza, M. D. A., Rossi, A. A. B., Varela, T. L., Silveira, G. F., \& Souza, S. A. M. (2016). Stigmatic receptivity and pollen viability of Theobroma subincanum mart.: Fruit species from the amazon region. Rev. Bras. Frutic, 38(4). https://doi.org/10.1590/0100-29452016757

Fernandes, M. S. (2006). Nutrição mineral de plantas. Viçosa: SBCS.

Figueiredo, R. W., Maia, G. A., Holanda, L. F. F., \& Monteiro, J. C. S. (1986). Phvsical and chemical characteristis of genipap fruit. Pesq. Agropec. Bras., 21(4), 421-428.

Food and Agriculture Organization of the United Nations (FAO). (1989). Retrieved from http://www.fao.org/ docrep/field/003/ab492s/ab492s04.htm

Food and Agriculture Organization of the United Nations (FAO). (2002). Retrieved from http://www.fao.org/ docrep/006/w0073s/w0073s0d.htm\#bm13

Food and Agriculture Organization of the United Nations (FAO). (2014). Retrieved from http://www.fao.org/ 3/a-i3592s.pdf

Franco, C. (1982). Texto básico e tabela de composição química dos alimentos (6th ed.). Rio de Janeiro: Atheneu.

Gabarra, A. G. (2006). Ingesta de Nutrientes: Conceptos y Recomendaciones Internacionales ( $1^{\mathrm{a}}$ Parte). Nutr Hosp, 21(3), 291-299.

García, A. E. Z. (2002). El envejecimiento y el estrés oxidativo. Rev Cubana Invest Biomed, 21(3), 178-185.

Giada, M. L. R., \& Mancini-Filho, J. (2006). Importância dos compostos fenólicos da dieta na promoção da saúde humana. Publ. UEPG Ci. Biol. Saúde, Ponta Grossa, 12(4), 7-15.

Gondim, J. A., Moura, M. F. V., Dantas, A. S., Medeiros, R. L. S., \& Santos, K. M. (2005). Composição Centesimal e de minerais em Cascas de frutas. Ciênc. Tecnol. Aliment., 25(4), 825-827. https://doi.org/ 10.1590/S0101-20612005000400032

Instituto Adolfo Lutz. (2008). Métodos físico-químicos para análise de alimentos (4th ed.). São Paulo: Instituto Adolfo Lutz.

Jorge, N., \& Luzia, D. M. M. (2012). Characterization of seed oil Pachira aquatic Aublet for food utilization. Acta Amazônica, 42(1), 149-156. https://doi.org/10.1590/S0044-59672012000100017 
Junior, E. N. O., Dos Santos, C. D., Abreu, C. M. P., Corrêa, A. D., \& Santos, J. Z. L. (2003). Nutritional analysis of "fruta-de-lobo" (Solanum lycocarpum St. Hil.) during the ripening process. Ciênc. Agrotec., 27(4), 846-851. https://doi.org/10.1590/S1413-70542003000400016

Kirkby, E. A., \& Römheld, V. (2007). Micronutrientes na fisiologia de plantas: funções, absorção e mobilidade. Encarte do Informações Agronômicas, 118, 1-24.

Kuskoski, E. M., Asuero, A. G., Morales, M. T., \& Fett, R. (2006). Wild fruits and pulps of frozen fruits: Antioxidant activity, polyphenols and anthocyanins. Ciência Rural, 36(4), 1283-1287. https://doi.org/ 10.1590/S0103-84782006000400037

Laviola, B. G., \& Dias, L. A. S. (2008). Nutrient concentration in Jatropha curcas L. leaves and fruits and estimated extraction at harvest. Revista Brasileira de Ciência do Solo, 32(5), 1969-1975. https://doi.org/ 10.1590/S0100-06832008000500018

Lorenzi, H. (1992). Árvores brasileiras: Manual de identificação e cultivo de plantas arbóreas nativas do Brasil. Nova Odessa: Plantarum.

Luzia, D. M. M. (2012). Propriedades funcionais de óleos extraídos de sementes de frutos do cerrado brasileiro (Doctoral dissertation, Paulista State University, Brazil).

Maciel, M. A. M., Pinto, A. C., \& Viega Jr., V. F. (2002). Medicinal plants: the need for multidisciplinary scientific studies. Química Nova, 25(3), 429-438. https://doi.org/10.1590/S0100-40422002000300016

Marques, L. G. (2008). Liofilização de frutas tropicais (Doctoral dissertation, University Federal of São Carlos, Brazil).

Martins, A. G., Rosário, D. L., Barros, M. N., \& Jardim, M. A. G. (2005). Levantamento etnobotânico de plantas medicinais, alimentares e tóxicas da Ilha do Combu, Município de Belém, Estado do Pará, Brasil. Rev. Bras. Farm, 86(1), 21-30.

Maury, E., Mattei, A., Perozo, K., Bravo, A., Martínez, E., \& Vizcarra, M. (2010). Niveles Plasmáticos de Hierro, Cobre y Zinc em escolares Barí. Pediatr, 37(2), 112-117.

Menezes, E. M. S., Torres, A. T., \& Srur, A. U. S. (2008). Lyophilized açaí pulp (Euterpe oleracea, Mart.) nutritional value. Acta Amazonica, 38(2), 311-316. https://doi.org/10.1590/S0044-59672008000200014

Miranda, A. L. P., \& Fraga, C. A. M. (2006). Atividade Seqüestradora de Radical Livre Determinação do Potencial Antioxidante de Substâncias Bioativas. In A. Monge, \& C. R. Ganellin (Eds.), Pratical Studies for Medicinal Chemistry. Genebra: IUPAC.

Monge, E., Val, J., Sanz, M., Blanco, A., \& Montañés, L. (1994). El calcio nutriente para las plantas Bitter pit en manzano. An. Estac. Exp. Aula Dei, Zaragoza, 21(3), 189-201.

Mors, W. B., Rizzini, C. T., Pereira, N. A., \& De Filipps, R. A. (2000). A Medicinal Plants of Brazil. Michigan: Algonac.

Murray, R. K. (2014). Bioquímica ilustrada de Harper (29th ed.). Porto Alegre: Artmed.

Nogueira, F. A. G., \& Canniatti-Brazaca, S. G. (2008). Disponibilidade de cálcio em leites integral e desnatado adicionados de frutas, café e achocolatado. B. CEPPA, 26(2), 213-228. https://doi.org/10.5380/cep.v26i2. 13277

Omena, C. M. B., Valentim, I. B., Guedes, G. S., Rabelo, L. A., Mano, C. M., Bechara, E. J. H., ... Goulart, M. O. F. (2012). Antioxidant, anti-acetylcholinesterase and cytotoxic activities of ethanol extracts of peel, pulp and seeds of exotic Brazilian fruits Antioxidant, anti-acetylcholinesterase and cytotoxic activities in fruits. Food Research International, 49(1), 334-344. https://doi.org/10.1016/j.foodres.2012.07.010

Panato, E., Junior, A. W., Cotta, R. M. M., Peluzio, M. C. G., Tinôco, A. L. A., \& Bruckner, C. H. (2007). Promoção da saúde: a importância das frutas e hortaliças e seu papel no câncer. O mundo da Saúde, 31(3), 384-393.

Porras, L. A. P., \& López, M. A. (2009). Importancia de los grupos fenólicos en los alimentos. Temas Selectos de Ingieneria de Alimentos, 3(1), 121-134.

Porto, R. G. C. L., Cardoso, B. V. S., Barros, N. V. A., Cunha, E. M. F., Araújo, M. A. M., \& Moreira-Araújo, R. S. R. (2014). Chemical Composition and Antioxidant Activity of Genipa americana L. (Jenipapo) of the Brazilian Cerrado. Journal of Agriculture and Environmental Sciences, 3(4), 51-61. https://doi.org/ 10.15640/jaes.v3n4a4 
Rabbani, A. R. C., Silva-Mann, R., \& Ferreira, R. A. (2012). Genetic variability of Genipa americana L. belonging to the lower course of São Francisco river. Revista Árvore, 36(3), 401-409. https://doi.org/ $10.1590 / \mathrm{S} 0100-67622012000300002$

Rezende, L. C. (2010). Avaliação da atividade antioxidante e composição química de seis frutas tropicais consumidas na Bahia (p. 118, Tese, Doctoral thesis, Federal University of Bahia, Brazil).

Rocha, F. D., Pereira, R. C., Kaplan, M. A. C., \& Teixeira, V. L. (2007). Produtos naturais de algas marinhas e seu potencial antioxidante. Revista Brasileira de Farmacognosia, 17(4), 631-639. https://doi.org/10.1590/ S0102-695X2007000400024

Ross, M. (2004). Importancia del magnesio para altos rendimientos sostenibles em palma de aceite. PALMAS, 25(2), 98-104.

Rufino, M. S. M., Alves, R. E., Brito, E. S., Morais S. M., Sampaio, C. G., Jiménez, J. P., \& Calixto, F. D. S. (2007). Metodologia Científica: Determinação da Atividade Antioxidante Total em Frutas pela Captura do Radical Livre DPPH. Fortaleza, EMBRAPA.

Santana-Neta, L. G. (2014). Caracterização e avaliação do potencial de bioativos e atividade antioxidantes de Genipa americana L. (Master Thesis of Science in Food Science, Federal University of Bahia, Brazil).

Schaafsma, A., De Vries, P. J., \& Saris, W. H. (2001). Delay of natural bone loss by, higher intakes of specific minerals and vitamins. Crit Rev Food Sci Nutr, 41(3), 225-228. https://doi.org/10.1080/20014091091805

Silva, L. A., Resende, O., Virgolino, Z. Z., Bessa, J. F. V., Morais, W. A., \& Vidal, V. M. (2015). Drying kinetics and effective diffusivity in jenipapo sheets (Genipa americana L.). Rev. Bras. Pl. Med., 17(4), 953-963. https://doi.org/10.1590/1983-084X/14_106

Singlenton, V. L., Orthofer, R., \& Lamuela-Raventos, R. M. (1999). Analysis of total phenols and other oxidation substrates and antioxidants by means of Folin-Ciocalteu reagent. Methods in Enzymology, 299, 152-178. https://doi.org/10.1016/S0076-6879(99)99017-1

Soares, A. C. F., Sousa, C. S., Garrido, M. S., \& Lima, F. S. (2012). Arbuscular mycorrhizal fungi in the growth and nutrition of jenipapo fruit tree seedlings. Revista Ciência Agronômica, 43(1), 47-54. https://doi.org/ $10.1590 / \mathrm{S} 1806-66902012000100006$

Tortara, G. J., \& Derrickson, B. (2017). Corpo Humano: Fundamentos de Anatomia e Fisiologia (10th ed.). Porto Alegre: Artmed.

Tovar, M. Á. O. (2003). Valor nutrimental de la pulpa fresca de aguacate hass. Actas V Congreso Mundial del Aguacate (pp. 741-748).

Tresguerres, J. A. F., Lugo, E. A. B. D., Cachofeiro, M. V., \& Cardinali, D. (2005). Fisiología Humana (3rd ed.). Lisboa: Mc Graw Hill Interamericana.

WHO (World Health Organization). (2003). Retrieved from http://www.who.int/mediacentre/news/releases/ 2003/pr20/es

WHO (World Health Organization). (2013). Retrieved from http://www.apps.who.int/iris/bitstream/10665/ 85226/1/WHO_NMH_NHD_13.1_spa.pdf?ua $=1 \& u a=1$

Wolfe, K., Wu, X., \& Liu, R. H. (2003). Antioxidant activity of apple peels. J. Agric Foof Chem, 51(3), 609-614. https://doi.org/10.1021/jf020782a

\section{Copyrights}

Copyright for this article is retained by the author(s), with first publication rights granted to the journal.

This is an open-access article distributed under the terms and conditions of the Creative Commons Attribution license (http://creativecommons.org/licenses/by/4.0/). 